\title{
Comparative Analysis of Banking Financial Performance: Evidence From Indonesia
}

\author{
*Indra Prasetyo, Universitas Wijaya Putra Indonesia, indraprasetyo@uwp.ac.id \\ Woro Utari, Universitas Wijaya Putra Indonesia, woroutari@uwp.ac.id \\ Hadi Susanto*, Universitas Wijaya Putra Indonesia, hadisusanto@uwp.ac.id \\ Rusdiyanto, Universitas Airlangga Indonesia and Universitas Gresik, rusdiyanto.se.m.ak- \\ 2017@feb.unair.ac.id \\ Widi Hidayat, Universitas Airlangga Indonesia, widi-h@feb.unair.ac.id \\ * Corresponding Author
}

\begin{abstract}
This research empirically explores the financial performance results of Indonesia Stock Exchange listed companies for seven years for the period 2010 to 2017 between PT BTN,Tbk (Persero) and PT BRI,Tbk (Persero). The financial ratio used consists in the ratio of capital adequacy, net profit margin, returns on assets, non-performing loans and deposit-related loans. This study only used a sample of two conventional banking companies in Indonesia, namely PT BTN,Tbk (Persero) and PT BRI,Tbk (Persero). Results from this research show that the PT BRI,Tbk (Persero) variabel Net Profit Margin, variabel Return on Asset Ratio, variabel Loan on Deposit, and variabel Capital Adequacy Ratio is better than PT BTN,Tbk (Persero). However, for variabel Non-Performing Loans, PT BTN,Tbk (Persero) is better than PT BRI,Tbk (Persero).
\end{abstract}

Keywords: CAR, NPL, NPM, ROA, LDR

$\begin{array}{lll}\text { Received: 08.12.2020 } & \text { Accepted: 14.01.2021 } & \text { Published: 07.02.2021 }\end{array}$

\section{INTRODUCTION}

The issue is that PT Bank Tabungan Negara Tbk (PT BTN Tbk (Persero)) cooperates with the Republic of Indonesia Employee Corps as outlined in a Memorandum of Understanding (MoU) or Memorandum of Understanding on Provision of Banking Services and Services. With this cooperation, it provides an opportunity for PT BTN Tbk (Persero) to provide banking services. While PT Bank Rakyat Indonesia Tbk (PT BRI Tbk (Persero)) said earlier this year that it would launch the latest features in its banking digitization service. The service is a cash withdrawal service without using an Automated Teller Machine (ATM) card. This was stated by the Consumer Director of Bank Rakyat Indonesia Handayani after attending the extraordinary public shareholders meeting of Bank Rakyat Indonesia at Jakarta. PT BRI Tbk (Persero) claimed to have signed an MoU regarding cooperation with server-based foreign payment system service providers such as Alipay.

Whereas (Syahputra \& Ahsanul Fuad Saragih, 2018) explained the Analysis of Soundness in the Bank using the CAMEL method for 2010-2014 at PT BRI Tbk (Persero), said to Bank Rakyat Indonesia, indicating that the capital of Capital Adequency Ratio in this bank was said to be healthy because the presentation of results was above the 2004 Bank Indonesia regulatory standard that is $12 \%$, productive asset quality factor with ratio Non Performing Loan shows a presentation of less than $3 \%$ means that the smaller the Non Performing Loan, the lower the risk of the bank's bad credit, and the healthier the quality of productive assets, Management Factors with ratio Net Profit Margin to get a fairly healthy predicate means that the manager in managing and controlling the bank must be increased to produce maximum profit, Profitability with Return on Assets (ROA) and BOPO ratio in healthy predicate and liquidity factor with ratio loan to deposit ratio get a healthy predicate. The difference between this research and the previous one lies in the object and the research period, namely at PT Bank Rakyat Indonesia Tbk (Persero) in 2010-2017, as well as additional financial ratios used.

\section{LITERATURE STUDY}

\section{The Bank Definition}

Law Number 10 Year 1998, (Indonesia, 1998) explain about banking, what the Bank means is " Enterprises that collect funds as deposits from the public and distribute it in loans to the public and other ways to improve many people's lives (Murphy, 2014), (Sani et al., 2018), (Hartono \& Diansyah, 
2018). Whereas According (Syahputra \& Ahsanul Fuad Saragih, 2018) Bank is an organization that receives community funds by deposit and by distribution to the community in a loan or other form to boost people's living standards. While banking comprises three activities: fund-raising, the channeling of funds and the provision of other bank services.(Syahputra \& Ahsanul Fuad Saragih, 2018).

Banking is an institution financial that has a significant financial role in Indonesia. This is because banks are institutions that have a main function, that is as a financial intermediary between funded parties and those who need funds and institutions that work to allow the integration of payment traffic. (Sani et al., 2018). This role is carried out by banks to facilitate the flow of payments and services to the community (Sani et al., 2018). Banking is a financial institution with main activities in which funds are collected from the public and redistributed to the community and other services are provided. (Sani et al., 2018). Financial statements is an overview of the financial condition of a company at any given moment. Financial statements are broadly divided into 4 types, namely the balance sheet, Statement of income, report of capital change and statement of cash flow (Sani et al., 2018).

A simple definition of financial statement is the report that at this time in a time frame shows The company's financial situation The purpose of the financial statements is to show the company's current condition. The latest condition of the company is the company's financial condition on a certain date (for balance sheets) and a period for profit and loss. Financial statements are usually made per period, for example three months, or six months for the company's internal interests, while for more extensive reports carried out once a year. Through the financial statements, the latest company position can be identified after analyzing the financial statements (Sani et al., 2018). Based on these definitions, the researcher can conclude that Deposit collection is the main business of the bank from the community that are the source of bank funds, then channel them in the form of credit, which should not only be motivated by the motive of maximizing profits for owners standard of living for its customers.

\section{Bank Functions}

The main function of the banks in general to raise the money from the public and to redirect it to the Community as a financial intermediary or for different purposes. Specifically, bank functions are detailed as follows (Sani et al., 2018) there are three indicators, namely:

\section{Agent of Trust}

Banking activities are based on trust or trust, both in fund collection and in the channeling of funds. The community will want the bank to deposit its funds when based on a trust element, and the bank will provide the community with funds if the trust element exists, (Sani et al., 2018).

\section{Analysis of Bank Soundness Using the CAMEL Ratio}

Regulation No.9/1/PBI/2007 of Bank Indonesia CAMEL's one way to measure bank performance. CAMEL is a Bank of Indonesia's official measurement tool to measure Islamic banking health in Indonesia. According to (Sani et al., 2018) one way to assess the soundness of the bank includes Capital assessment, asset quality, management, income and liquidity considerations. The method of evaluating bank financial performance regarding the level of bank health according to Bank Indonesia standards uses five aspects known as CAMEL, (Sani et al., 2018).

Definition of CAMEL financial ratios according (Syahputra \& Ahsanul Fuad Saragih, 2018; Akter et al., 2018; Masood et al., 2016; Pekkaya \& Demir, 2018; Rashid \& Jabeen, 2016; Rout et al., 2019) are: aspects that most impact on the financial situation of the bank, which also affect the bank's health. CAMEL is an item of banking controls performed by the supervisors of banking services. CAMEL comprises five criteria: equity, assets, administration, income and liquidity, (Aabdel-Salam \& El-Sayed, 2014; Ababneh, 2013; Abad-González \& Gutiérrez-López, 2016; Abad-Vivero et al., 2016; Abarghani et al., 2019; Abdul Rahman \& Masngut, 2014).

\section{Capital Factors}

The capital adequacy ratio displays the bank's ability to provides funds to overcome the potential loss risk. An examination of the capital factor seeks to determine if and how much the bank capital is necessary to finance its business (A. M. Ali, 2020; Dang, 2020; Killins \& Mollick, 2020; Merikas et al., 2020; Navas et al., 2020; SASIDHARAN et al., 2020; Wijaya et al., 2020). Risk Weighted Assets is the sum of balance sheet assets and administrative assets. Risk Weighted Assets for balance sheet assets is obtained by multiplying the nominal value of the asset concerned with the risk weight. Whereas Risk Weighted Assets of administrative assets is obtained by multiplying the value of the administrative assets of the account concerned with the risk weight, (Ahmad, Naveed, Ahmad, \& Butt, 2020; Dudchenko, Goncharenko, Didenko, \& Olejarz, 2020; Ibrahim \& Law, 2020; Meslier, Risfandy, \& Tarazi, 
2020; Naseri, Bacha, \& Masih, 2020; Sani et al., 2018), (Suryansyah \& Rusdiyanto, 2016) so that this assessment is based on Ratio of the Capital Adequacy by Bank Indonesia, the calculation is as follows:

$\mathrm{CAR}=\frac{\text { Capital }}{\text { Risk Weighted Assets }} \times 100 \%$

\section{Agent of Development}

The monetary sector and the real sector have interactions that influence each other. If not supported by a monetary sector, the real sector will not work well. So that the bank's activities in raising funds and channeling it to the public allow the community to distribute, invest, consume also goods and services, these activities have to do with the use of money. And the smooth running of these activities encourages economic development in society, (Gazali, Kusuma, Aina, Bustaram, Risal, et al., 2020; Juanamasta et al., 2019; Rusdiyanto, Hidayat, Soetedjo, et al., 2020; Rusdiyanto, Sawarjuwono, \& Tjaraka, 2020; Rusdiyanto et al., 2019; Sani et al., 2018).

\section{Service of Agent}

In addition to the collection and transmission of money, banks also provide the public with other banking services that are closely linked to the community's overall economical activities, such as money transfer services, valuation services, and bill settlement services, (Sani et al., 2018; (Hristov et al., 2020; Julsrud \& Denstadli, 2020; Kerléo, 2020; Kim et al., 2020; Peled et al., 2020).

\section{Asset Quality Factors}

In normal conditions most of the assets of a bank consists of a loan and other assets which can generate or become an income source for the bank so that assets of the type are productive assets. According to (Syahputra \& Ahsanul Fuad Saragih, 2018). The assessment builds on performance of the income property owned by the bank's income ratio that is grouped into production assets. To measure the level of opportunity to receive back invested funds, this ratio is used. Non Performing Loans is to see how much the level of non-performing loans is disbursed by the bank. Bank Indonesia provides a maximum standard rule of 5\% for the value of Non Performing Loans, (S. Z. M. Abbas et al., 2017; Z. Abbas \& Faisal Rizwan, 2007; Abdul Hadi, Hussain, Suryanto, \& Eddy Yap, 2018; Abdul Hadi, Hussain, Suryanto, \& Yap, 2018; Abdul Karim et al., 2014; Abdul Rahman \& Masngut, 2014; Abdullah et al., 2017; Aboagye \& Ahenkora, 2018)so that this assessment is based on the Non Performing Loan set by Bank Indonesia, the calculation is as follows:

$N P L=\frac{\text { Bad Credit }}{\text { Total Credit }}$

\section{Management Factors}

Bank management will decide whether a bank is healthy or not. Given this, bank management takes great care in assessing the bank's soundness, a banks are expected to build and maintain their health, assessing aspects of management using the Net Profit Margin ratio. According to (Syahputra \& Ahsanul Fuad Saragih, 2018), Net Profit Margin are a " ratios used to measure bank capacity generating net income from its principal operating activities", (McCue \& Stack, 2015), (Hermanto et al., 2018), (Piu et al., 2018), (Erdawati \& Bachtiar, 2018) so that this assessment is based on the Non Profit Margin set by Bank Indonesia, the calculation is as follows:

$\mathrm{NPM}=\frac{\text { Net profit }}{\text { operating income }} \times 100 \%$

\section{Factors of Rentability (earning)}

According to (Syahputra \& Ahsanul Fuad Saragih, 2018) assessment In this element, two types are based, namely:

1. Total ROA is used to measure banks' efficiency in achieving total benefits.

1. Operating expenses are a comparison of operating expenditure with operating revenue.

The analysis of bank profitability ratios are used to measure the efficiency and profitability of the bank concerned (Gazali et al., 2020; Rusdiyanto, Agustia, Soetedjo, \& Septiarini, 2020; Rusdiyanto, Hidayat, et al., 2020; Rusdiyanto \& Narsa, 2019). Rentability is measured using two calculations as follows:

$R O A=\frac{\text { Net Income }}{\text { Total Asset }}$ 


\section{Liquidity Factors}

This liquidity aspect is focused on the readiness of the bank to pay all of its debts, current accounts, especially savings, and time deposits if billed and all credit applications worthy of approval can be completed. According (Syahputra \& Ahsanul Fuad Saragih, 2018), Ratio of Loan to Deposit Ratio is a " State's ratio how far the bank has used depositors to provide loans to its customers". Analysis of liquidity in this study can be measured by the ratio of Loan to Deposit, which is a ratio for measuring credit composition given in relation to the amount of government money and own capital employed; (Adeabah et al., 2019; M. Ali et al., 2019; An \& Yu, 2018; Anggono, 2017; Ariefianto et al., 2020), The formula for finding a Ratio of Loan to Deposit is as follows (Circular No. 6/23/DPNP from the Indonesian Bank of 31 May 2004):

$\mathrm{LDR}=\frac{\text { total credit to third parties not banks }}{\text { total credit to third parties }} \times 100 \%$

\section{RESEARCH METHODS}

This research was conducted at PT BRI Tbk (Persero) and PT BTN Tbk (Persero) which are listed in 2010-2017 on Indonesia Stock Exchange (I.G. Juanamasta, Wati, Hendrawati, Wahyuni, Pramudianti, Wisnujati, Setiawati, Susetyorini, Elan, Rusdiyanto, Muharlisiani, et al., 2019; Prabowo et al., 2020; Rusdiyanto et al., 2020; Rusdiyanto, Hidayat, Tjaraka, Septiarini, Fayanni, Utari, Waras, Indrawati, Susanto, Tjahjo, Zainal, et al., 2020; Syafii et al., 2020). Types and data sources that the author uses in this writing the author uses secondary data. In this study, we used data financial statement data in 2010-2017 from indonesia stock exchange. And supported by library studies to obtain reference sources that support this research, namely in the form of financial statements of PT BRI Tbk (Persero) and PT BTN Tbk (Persero). The data sources used are internal and external data derived from the publication of financial statements in www.idx.co.id which consists of Financial Position Reports, Profit-Loss Reports, Cash Flow Reports, Equity Change Report and Financial statements Notes.

\section{Documentation Study Methods}

This method is done by finding and studying data and recording written data on matters in the form of notes or documents from research object related companies. The documentation method in this research is to retrieve financial report data at Indonesia Stock Exchange (I.G. Juanamasta, Wati, Hendrawati, Wahyuni, Pramudianti, Wisnujati, Setiawati, Susetyorini, Elan, Rusdiyanto, Astanto, et al., 2019; Prabowo et al., 2020; Rusdiyanto et al., 2020; Rusdiyanto, Hidayat, Tjaraka, Septiarini, Fayanni, Utari, Waras, Indrawati, Susanto, Tjahjo, Mufarokhah, et al., 2020b).

Data Collection

In the study, the data collection method is a method with a literature study which means that the data is secondary. Secondary data is data obtained from sources which exist and which the researchers themselves don't need to collect. Secondary data obtained as secondary data from sources that exist and do not need to be collected by the researchers themselves. Secondary data can be obtained on Indonesia Stock Exchange as the financial statements in 2010-2017. In addition, in this study the method of data collection uses library studies related to the problems being studied as well as material that is theoretical and relevant to be used as a reference through literature, journals, articles, internet, which can assist in solving problems related to research titles related to the comparison of financial performance with the camel method. In this study using statistical techniques in the form of two different test averages (Independent t-test sample).

Data Analysis

The purpose of testing the hypothesis in the form of two different tests on average in this study is to determine the accept or reject the hypothesis that has been made as follows:

"If $\mathrm{F}$ counts with the Equal variance assumed (assumed to be the same two variances) has a sig value. $>0.05$, it is stated that the two variants are the same. If the two variances are the same, then you should use the Equal variance assumed basis (assuming the two variants are the same) for $t$ count. If $t$ count sig. $<0.05$, it is said that the financial performance of PT BRI,Tbk (Persero) with the State Savings PT BTN,Tbk (Persero) has a significant difference, on the contrary if $t$ count sig> 0.05 it is stated that the financial performance of PT BRI,Tbk (Persero) with the State Savings Bank Persero Tbk has no significant difference. If $\mathrm{F}$ counts with the Equal variance assumed (assumed to be the same two variances) has a sig value. $<0.05$, it is stated that the two variances are different. If the two variances are different, then comparing the two populations with $t$ test should use the basis of Equal variance not assumed (assuming the two variants are not the same) for $t$ count. If $t$ counts with Equal variance not assumed to have sig. $>0.05$, it can be said that the financial performance of PT BRI,Tbk (Persero) with 
the PT BTN Tbk (Persero) does not have a significant difference, but if sig. $<0.05$, it can be stated that the financial performance of PT BRI Tbk (Persero) Tbk with PT BTN Tbk (Persero) has significant differences.

\section{RESULTS OF RESEARCH AND DISCUSSION}

\section{Results of Analysis of the Capital Adequacy Ratio}

Table 1. Statistics Capital Adequacy Ratio

\begin{tabular}{|l|l|l|l|l|l|}
\hline & BANK & $\mathrm{N}$ & Mean & Std. Deviation & Std. Error Mean \\
\hline CAR & Bank Rakyat Indonesia & 32 & 18,1781 & 2,84347 & 0,50266 \\
\hline & $\begin{array}{l}\text { Bank Tabungan } \\
\text { Negara }\end{array}$ & 32 & 16,9475 & 1,86381 & 0,34716 \\
\hline
\end{tabular}

PT BRI Tbk (Persero) Tbk has an average (mean) ratio of Capital Adequacy Ratio of 18,781, greater than the mean ratio of PT BTN Tbk (Persero) Capital Adequacy Ratio of 16,9475. This means that during the period 2010-2017 the PT BTN Tbk (Persero) has a better Capital Adequacy Ratio than PT BRI Tbk (Persero) Tbk, because the higher value of Capital Adequacy Ratio, the better the quality of the bank's capital. If referring to Bank Indonesia provisions that the best standard Capital Adequacy Ratio is $8 \%$, then PT BRI Tbk (Persero) Tbk is still in an ideal condition because it is still above Bank Indonesia regulations. PT BRI Tbk (Persero) Tbk standard deviation of 2.84347 shows a relatively small deviation of data, because its value is smaller than its mean value of 18.1781. The standard deviation of the PT BTN Tbk (Persero) amounting to 1.86381 also shows a deviation of data that is relatively small compared to its mean value, which is equal to 16.9475 . With the small deviation of data, it shows that the variable Capital Adequacy Ratio is quite good.

Table 2. Independent Sample Test Capital Adequacy Ratio

\begin{tabular}{|c|c|c|c|c|c|c|c|c|c|c|}
\hline & & \multicolumn{2}{|c|}{\begin{tabular}{lr}
\multicolumn{2}{l}{ Levene's } \\
Test for \\
Equity of \\
Variace
\end{tabular}} & \multicolumn{7}{|c|}{ t-test for Equiality of Mean } \\
\hline & & \multirow[t]{2}{*}{$\mathrm{F}$} & \multirow[t]{2}{*}{ Sig } & \multirow[t]{2}{*}{$\mathrm{t}$} & \multirow[t]{2}{*}{$\mathrm{df}$} & \multirow{2}{*}{$\begin{array}{l}\text { Sig. } \\
\text { (sta } \\
\text { iled } \\
\text { ) }\end{array}$} & \multirow{2}{*}{$\begin{array}{l}\text { Mean } \\
\text { diferen } \\
\text { ce }\end{array}$} & \multirow{2}{*}{$\begin{array}{l}\text { Std } \\
\text { Error } \\
\text { difer } \\
\text { ence }\end{array}$} & \multicolumn{2}{|c|}{$\begin{array}{l}95 \% \text { Confidence } \\
\text { interval of the } \\
\text { difference }\end{array}$} \\
\hline & & & & & & & & & Lower & Upper \\
\hline $\begin{array}{l}\text { CA } \\
\mathrm{R}\end{array}$ & $\begin{array}{ll}\text { Equal } & \text { Variances } \\
\text { Assumed } & \end{array}$ & 6,287 & $\begin{array}{l}0,0 \\
15\end{array}$ & 2,014 & 62 & $\begin{array}{l}0,0 \\
48\end{array}$ & $\begin{array}{l}1,2306 \\
3\end{array}$ & $\begin{array}{l}0,610 \\
89\end{array}$ & $\begin{array}{l}0,0094 \\
8\end{array}$ & $\begin{array}{l}2,4517 \\
7\end{array}$ \\
\hline & $\begin{array}{l}\text { Equal Variances } \\
\text { notAssumed }\end{array}$ & & & 2,014 & $\begin{array}{l}55,09 \\
2\end{array}$ & $\begin{array}{l}0,0 \\
48\end{array}$ & $\begin{array}{l}1,2306 \\
3\end{array}$ & $\begin{array}{l}0,610 \\
89\end{array}$ & $\begin{array}{l}0,0064 \\
3\end{array}$ & $\begin{array}{l}2,4548 \\
2\end{array}$ \\
\hline
\end{tabular}

The results of the Independent Test Sample statistical test $\mathrm{F}$ for Capital Adequacy Ratio with equal variance assumed (assumed to be the same variance) is 6.287 with a probability of 0.015 . Because the probability of the data above is greater than 0.05 , No difference in variance can be said to exist in the comparative financial performance data of PT BRI Tbk (Persero) Tbk with PT BTN Tbk (Persero) for the Capital Adequacy Ratio. If both variances are the same, Equal Variances Assumed is used. $t$ count for Capital Adequacy Ratio using Equal Variances Assumed is 2.014 with a significant value of 0.048 . Because of the sig value. $\mathrm{t}$ hittung $<\mathrm{t}$ table $(0.048<0.005)$, it can be said that when viewed from the Capital Adequacy Ratio, the financial performance of PT BRI Tbk (Persero) Tbk with PT BTN Tbk (Persero) there are significant differences.

\section{Results of Non-Performing Loan Ratio Analysis}

Table 3. Statistics Non-Performing Loan

\begin{tabular}{|l|l|l|l|l|l|}
\hline & BANK & $\mathrm{N}$ & Mean & Std. Deviation & Std. Error Mean \\
\hline NPL & Bank Rakyat Indonesia & 32 & 0,7703 & 0,33744 & 0,05965 \\
\hline & $\begin{array}{l}\text { Bank Tabungan } \\
\text { Negara }\end{array}$ & 32 & 3,0091 & 0,65500 & 0,11579 \\
\hline
\end{tabular}


PT BRI Tbk (Persero) Tbk has a mean Non-Performing Loan ratio of 0.7703, smaller than the mean ratio of Non-Performing Loans at PT BTN Tbk (Persero) 3.0091. This means that during the period 2010-2017 the PT BTN Tbk (Persero) has a Non-Performing Loan better than PT BRI Tbk (Persero) Tbk, because the lower the value of Non-Performing Loans, the better asset quality of a bank. However, if it refers to Bank Indonesia regulations that the best Non-Performing Loan standard is below 5\%, then PT BRI Tbk (Persero) Tbk is still in an ideal condition because it is still Indonesia Bank in accordance with the rules. The standard deviation of PT BRI Tbk (Persero) Tbk amounting to 0.33744 shows a relatively small deviation of data, because the value is smaller than the mean value of 0.7703. The standard deviation of Bank Tabungan Negara Persero, amounting to 0.65500, also shows a deviation of data that is relatively small compared to its mean value, which is equal to 0.7703 . With the small data deviation, it shows that the data on the Non-Performing Loan variable is quite good.

Table 4. Independent Sample Test Non-Performing Loan

\begin{tabular}{|c|c|c|c|c|c|c|c|c|c|c|}
\hline & & \multicolumn{2}{|c|}{$\begin{array}{l}\text { Levene's Test } \\
\text { for Equity of } \\
\text { Variace }\end{array}$} & \multicolumn{7}{|c|}{ t-test for Equiality of Mean } \\
\hline & & \multirow[t]{2}{*}{$\mathrm{F}$} & \multirow[t]{2}{*}{ Sig } & \multirow[t]{2}{*}{$\mathrm{t}$} & \multirow[t]{2}{*}{ df } & \multirow{2}{*}{\begin{tabular}{|l|} 
Sig. \\
(sta \\
iled \\
)
\end{tabular}} & \multirow{2}{*}{$\begin{array}{l}\text { Mean } \\
\text { diferen } \\
\text { ce }\end{array}$} & \multirow{2}{*}{$\begin{array}{l}\text { Std } \\
\text { Error } \\
\text { difer } \\
\text { ence }\end{array}$} & \multicolumn{2}{|c|}{$\begin{array}{l}95 \% \text { Confidence } \\
\text { interval of the } \\
\text { difference }\end{array}$} \\
\hline & & & & & & & & & Lower & Upper \\
\hline $\begin{array}{l}\mathrm{NP} \\
\mathrm{L}\end{array}$ & $\begin{array}{l}\text { Equal Variances } \\
\text { Assumed }\end{array}$ & 22,77 & 0,000 & $\begin{array}{l}- \\
17,18 \\
8\end{array}$ & 62 & $\begin{array}{l}0,0 \\
00\end{array}$ & $\begin{array}{l}- \\
2,2387 \\
5\end{array}$ & $\begin{array}{l}0,130 \\
25\end{array}$ & $\begin{array}{l}- \\
2,4991 \\
2\end{array}$ & $\begin{array}{l}- \\
1,9783 \\
8\end{array}$ \\
\hline & $\begin{array}{l}\text { Equal Variances } \\
\text { notAssumed }\end{array}$ & & & $\begin{array}{l}- \\
17,18 \\
8\end{array}$ & $\begin{array}{l}46,37 \\
3\end{array}$ & $\begin{array}{l}0,0 \\
00\end{array}$ & $\begin{array}{l}- \\
2,2387 \\
5\end{array}$ & $\begin{array}{l}0,130 \\
25\end{array}$ & $\begin{array}{l}- \\
2,5008 \\
7\end{array}$ & $\begin{array}{l}- \\
1,9766 \\
3\end{array}$ \\
\hline
\end{tabular}

The results of the Independent Sample t-Test Statistical Test can be seen that the F count for NonPerforming Loans assumed with the same variance is 22,771 with a probability of 0,000 . Because the probability of the data above is smaller than 0.05 , it can be said that there is a difference in variance in the comparative financial performance data of PT BRI Tbk (Persero) Tbk with PT BTN Tbk (Persero) for the ratio of Non-Performing Loans. If both variances are the same, Equal Variances Assumed is used. $t$ count for Non-Performing Loans using Equal Variances Assumed is -17,188,215 with a significant amount of 0,000 . Because of the sig value. $t$ hitung $<t$ Table $(0,000<0,005)$, it can be said that when viewed from the ratio of Non-Performing Loans (NPL), the financial performance of PT BRI Tbk (Persero) Tbk with PT BTN Tbk (Persero) has no significant differences.

\section{Results of Analysis of Net Profit Margin Ratio}

Table 5. Group Statistics Net Profit Margin

\begin{tabular}{|l|l|l|l|l|l|}
\hline & BANK & $\mathrm{N}$ & Mean & Std. Deviation & Std. Error Mean \\
\hline NPM & Bank Rakyat Indonesia & 32 & 8,5844 & 0,62411 & 0,11033 \\
\hline $\begin{array}{l}\text { Bank Tabungan } \\
\text { Negara }\end{array}$ & 32 & 5,2169 & 0,64632 & 0,11425 \\
\hline
\end{tabular}

PT BRI Tbk (Persero) Tbk has an average (Net) ratio of Net Profit Margin (NPM) of 8.5844, greater than the mean ratio of Net Profit Margin (NPM) at PT BTN Tbk (Persero) 5,2169. This means that during the 2010-2017 period the People's Bank Indonesia Persero Tbk has a Net Profit Margin better than the PT BTN Tbk (Persero), because the higher the Net Profit Margin Ratio value the better the quality of management of a bank. Bank Indonesia provisions that the best Net Profit Margin standard is below 5\%, then PT BRI Tbk (Persero) Tbk is still in an ideal condition because it is still in accordance with Bank Indonesia regulations. PT BRI Tbk (Persero) Tbk standard deviation of 0.62411 shows a relatively small data deviation, because its value is smaller than its mean value of 8.5844 . The standard deviation of the PT BTN Tbk (Persero) amounting to 0.64632 also shows a deviation of data that is relatively small compared to its mean value, which is equal to 5.2169. With the small data deviation, it shows that the data on the Net Profit Margin (NPM) variable is quite good. 
Table 6. Independent Sample Test Net Profit Margin

\begin{tabular}{|c|c|c|c|c|c|c|c|c|c|c|}
\hline & & $\begin{array}{l}\text { Leve } \\
\text { Test } \\
\text { Fouit }\end{array}$ & for & t-test & or Equ & lity c & Mean & & & \\
\hline & & $\mathrm{F}$ & Sig & $\mathrm{t}$ & $\mathrm{df}$ & $\begin{array}{l}\text { Sig. } \\
\text { (st } \\
\text { aile } \\
\text { d) }\end{array}$ & $\begin{array}{l}\text { Mean } \\
\text { difere } \\
\text { nce }\end{array}$ & $\begin{array}{l}\text { Std } \\
\text { Erro } \\
\mathrm{r} \\
\text { difer }\end{array}$ & $\begin{array}{l}95 \% \\
\text { Confide } \\
\text { interva } \\
\text { differen }\end{array}$ & $\begin{array}{l}\text { of the } \\
\text { o }\end{array}$ \\
\hline & & & & & & & & ence & Lower & Upper \\
\hline $\begin{array}{l}\mathrm{NP} \\
\mathrm{M}\end{array}$ & $\begin{array}{l}\text { Equal Variances } \\
\text { Assumed }\end{array}$ & 0,38 & $\begin{array}{l}0,5 \\
36\end{array}$ & $\begin{array}{l}21,2 \\
02\end{array}$ & 62 & $\begin{array}{l}0,0 \\
00\end{array}$ & $\begin{array}{l}3,367 \\
50\end{array}$ & $\begin{array}{l}0,15 \\
883\end{array}$ & $\begin{array}{l}3,050 \\
01\end{array}$ & $\begin{array}{l}3,684 \\
499\end{array}$ \\
\hline & $\begin{array}{l}\text { Equal Variances } \\
\text { notAssumed }\end{array}$ & & & $\begin{array}{l}21,2 \\
02\end{array}$ & $\begin{array}{l}61,9 \\
24\end{array}$ & $\begin{array}{l}0,0 \\
00\end{array}$ & $\begin{array}{l}3,367 \\
50\end{array}$ & $\begin{array}{l}0,15 \\
883\end{array}$ & $\begin{array}{l}3,050 \\
00\end{array}$ & $\begin{array}{l}3,685 \\
00\end{array}$ \\
\hline
\end{tabular}

Results of the Sample t-Test Independent Statistical Test that is shown F count for Net Profit Margin with equal variance assumed (assumed to be the same two variances) is 0.387 with a probability of 0.536 . Because the probability of the data above is greater than 0.05 , it can be said there's no difference in variance in the comparative financial performance data of PT BRI Tbk (Persero) Tbk with PT BTN Tbk (Persero) for the Net Profit Margin ratio. If both variances are the same, Equal Variances Assumed is used. t count for Net Profit Margin using Equal Variances Assumed is 21.202 with a significant of 0.000 . Because of the sig value. $t$ hitung $<$ t Table $(0,000<0,005)$, it can be said that when viewed from the ratio of Net Profit Margin, the financial performance of PT BRI Tbk (Persero) Tbk with PT BTN Tbk (Persero) has no significant differences.

\section{Results of Return on Asset Ratio Analysis}

Table 7. Statistics Return on Asset

\begin{tabular}{|l|l|l|l|l|l|}
\hline & BANK & $\mathrm{N}$ & Mean & Std. Deviation & Std. Error Mean \\
\hline ROA & Bank Rakyat Indonesia & 32 & 4,2581 & 0,60040 & 0,10614 \\
\hline & $\begin{array}{l}\text { Bank Tabungan } \\
\text { Negara }\end{array}$ & 32 & 1,6841 & 0,29591 & 0,05231 \\
\hline
\end{tabular}

PT BRI Tbk (Persero) Tbk has an average return on assets (ROA) ratio of 4.2581, greater than the mean Return on Assets ratio at the PT BTN Tbk (Persero) amounting to 1.6841. This means that during the period 2010-2017 PT BRI Tbk (Persero) Tbk has a Return on Assets better than the PT BTN Tbk (Persero), because the greater the value Return on Assets, the better the quality. However, if it refers to the standard of Return on Assets of Bank Indonesia which is equal to 1.5\%, then PT BRI Tbk (Persero) Tbk is still in an ideal condition. The standard deviation of PT BRI Tbk (Persero) Tbk amounting to 0.60040 shows a relatively small data deviation, because its value is smaller than its mean value of 4.2581. The standard deviation of the PT BTN Tbk (Persero) amounting to 0.29591 also shows a deviation of data that is relatively small compared to the mean value, which is equal to 1.6841.

Table 8. Independent Sample Test Return on Asset

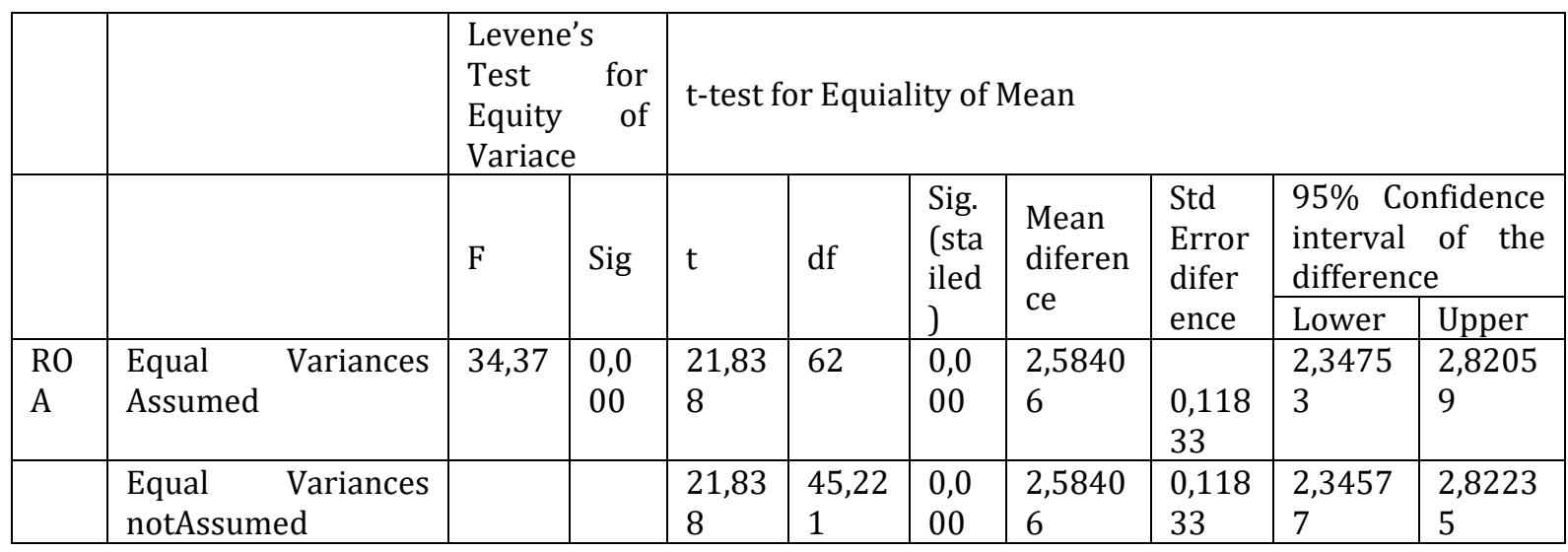


The results of the Independent Sample t-Test Statistical Test can be seen that F count for Return on Assets assumed to be equally different is 34,371 with a probability of 0,000 . Because the probability of the above data is smaller than 0.005 , It can be assumed that there are no variances in the comparative financial performance data of PT BRI Tbk (Persero) Tbk with PT BTN Tbk (Persero) for the Return on Assets ratio. If both variances are the same, Equal Variances Assumed is used. $t$ count for Return on Assets using Equal Variances Assumed is 21.838 with a significant of 0.000 . Because of the sig value. $t$ count $<$ t Table $(0,000<0,005)$, it can be said that when viewed from the Return on Assets ratio, the financial performance of PT BRI Tbk (Persero) Tbk with PT BTN Tbk (Persero) has no significant differences.

\section{Results of Analysis of Loan to Deposit Ratio}

Table 9. Group Statistics Loan to Deposit Ratio

\begin{tabular}{|l|l|l|l|l|l|}
\hline & BANK & $\mathrm{N}$ & Mean & Std. Deviation & Std. Error Mean \\
\hline LDR & Bank Rakyat Indonesia & 32 & 86,9303 & 4,52028 & 0,79908 \\
\hline & $\begin{array}{l}\text { Bank Tabungan } \\
\text { Negara }\end{array}$ & 32 & 107,8359 & 4,31868 & 0,76344 \\
\hline
\end{tabular}

PT BRI Tbk (Persero) Tbk has an average (mean) ratio of Loan to Deposit Ratio of 86,9303, smaller than the mean ratio of the Loan to Deposit Ratio at PT BTN Tbk (Persero) amounting to 107,8359. This means that during the period 2010-2017 PT BRI Tbk (Persero) Tbk had a better Loan to Deposit Ratio compared to the PT BTN Tbk (Persero). PT BRI Tbk (Persero) Tbk meets the best standard of Loan to Deposit Ratio from Bank Indonesia, amounting to 85-110\%, while PT BTN Tbk (Persero) does not meet the best standards of Bank Indonesia. The standard deviation of PT BRI Tbk (Persero) Tbk in the amount of 4,52028 shows a relatively small data deviation, because the value is smaller than the mean value of 86,9303. The standard deviation of the PT BTN Tbk (Persero) amounting to 4,31868 also shows a deviation of data that is relatively large compared to its mean value, which is equal to 107,8359 . With the large amount of data deviation, the variable data of the Loan to Deposit Ratio is not good.

Table 10. Independent Sample Test Loan to Deposit Ratio

\begin{tabular}{|c|c|c|c|c|c|c|c|c|c|c|}
\hline & & \multicolumn{2}{|c|}{$\begin{array}{l}\text { Levene's } \\
\text { Test for } \\
\text { Equity of } \\
\text { Variace } \\
\end{array}$} & \multicolumn{7}{|c|}{ t-test for Equiality of Mean } \\
\hline & & \multirow[t]{2}{*}{$\mathrm{F}$} & \multirow[t]{2}{*}{ Sig } & \multirow[t]{2}{*}{$\mathrm{t}$} & \multirow[t]{2}{*}{$\mathrm{df}$} & \multirow{2}{*}{$\begin{array}{l}\text { Sig. } \\
\text { (sta } \\
\text { iled } \\
\text { ) }\end{array}$} & \multirow{2}{*}{$\begin{array}{l}\text { Mean } \\
\text { diferen } \\
\text { ce }\end{array}$} & \multirow{2}{*}{$\begin{array}{l}\text { Std } \\
\text { Error } \\
\text { difer } \\
\text { ence }\end{array}$} & \multicolumn{2}{|c|}{$\begin{array}{l}95 \% \text { Confidence } \\
\text { interval of the } \\
\text { difference }\end{array}$} \\
\hline & & & & & & & & & Lower & Upper \\
\hline $\begin{array}{l}\mathrm{LD} \\
\mathrm{R}\end{array}$ & $\begin{array}{ll}\text { Equal } & \text { Variances } \\
\text { Assumed } & \end{array}$ & $\begin{array}{l}0,0 \\
01\end{array}$ & $\begin{array}{l}0,9 \\
81\end{array}$ & $\begin{array}{l}- \\
18,91 \\
6\end{array}$ & 62 & $\begin{array}{l}0,0 \\
00\end{array}$ & $\begin{array}{l}- \\
20,905 \\
63\end{array}$ & $\begin{array}{l}1,105 \\
16\end{array}$ & $\begin{array}{l}- \\
23,114 \\
80\end{array}$ & $\begin{array}{l}- \\
18,696 \\
45\end{array}$ \\
\hline & $\begin{array}{l}\text { Equal Variances } \\
\text { notAssumed }\end{array}$ & & & $\begin{array}{l}- \\
18,91 \\
6\end{array}$ & $\begin{array}{l}61,87 \\
1\end{array}$ & $\begin{array}{l}0,0 \\
00\end{array}$ & $\begin{array}{l} \\
20,905 \\
63\end{array}$ & $\begin{array}{l}1,105 \\
16\end{array}$ & $\begin{array}{l}- \\
23,114 \\
89\end{array}$ & $\begin{array}{l}- \\
18,696 \\
36\end{array}$ \\
\hline
\end{tabular}

The results of the Independent Sample t-Test Statistical Test can be seen that the calculated F for Loan to Deposit Ratio assumed to be equally different is 0.001 with a probability of 0.981 . Because the probability of the data above is greater than 0.05 , It can be assumed that there are no variances in the comparative financial performance data of PT BRI Tbk (Persero) Tbk with PT BTN Tbk (Persero) for the Loan to Deposit Ratio. If both variances are the same, Equal Variances Assumed is used. t count for Loan to Deposit Ratio using Equal Variances Assumed is -18,916 with a significant value of 0,000. Because of the sig value. $t$ count $<$ t Table $(0,000<0,005)$, it can be said that when viewed from the Loan to Deposit Ratio, the financial performance of PT BRI Tbk (Persero) Tbk with PT BTN Tbk (Persero) has no significant difference.

\section{DISCUSSION}

Capital Adequacy Ratio of PT BRI Tbk (Persero) Tbk is better than PT BTN Tbk (Persero), the average value of the two types of banks has met the Bank Indonesia regulatory standard of $8 \%$, but the average 
value of the two types of banks has a fairly large ratio. PT BTN Tbk (Persero) has a higher average value than PT BRI Tbk (Persero) Tbk, which means that the PT BTN Tbk (Persero) has better capital adequacy which is the basis for banks in developing their business activities, as well as having sufficient capital to supporting risk-bearing assets. This is identified because the influence of the own capital owned by the bank greatly affects the total assets owned.

Non-Performing Loan Ratio of PT BTN Tbk (Persero) is better than PT BRI Tbk (Persero) Tbk. The average value of the two types of banks has met Bank Indonesia's accuracy standard of 5\%, but the average value of the two types of banks has quite a large ratio. PT BTN Tbk (Persero) has a higher average value than PT BRI Tbk (Persero) Tbk, meaning that the PT BTN Tbk (Persero) has better capital adequacy which is the basis for banks in developing their business activities, and have sufficient capital to support riskbearing assets. Identified because the influence of own capital owned by banks greatly affects the total assets owned.

The Net Profit Margin of PT BRI Tbk (Persero) Tbk is better than the PT BTN Tbk (Persero). The average value of Net Profit Margin for the two types of banks has met the Bank Indonesia regulatory standard, which is equal to 81\%. However, PT BRI Tbk (Persero) Tbk has a comparatively high average value compared to the State Savings Bank Persero Tbk, which means that PT BRI Tbk (Persero) Tbk shows more the quality of bank management in identifying, measuring, monitoring and controlling the risks that arise.

Return on Bank Rakyat Indonesia Asset Persero Tbk is better than PT BTN Tbk (Persero). It can be seen that PT BRI Tbk (Persero) Tbk has a higher means value than the State Savings Bank Persero Tbk, which means that PT BRI Tbk (Persero) Tbk is more maximal in using its assets to generate net income. In the Return on ratio, the average asset value of PT BRI Tbk (Persero) Tbk and PT BTN Tbk (Persero) has exceeded the standard value determined by Bank Indonesia, which is equal to $1.5 \%$, has not reached the standard determined by Bank Indonesia.

Loan to Deposit Ratio of PT BRI Tbk (Persero) Tbk is better than PT BTN Tbk (Persero). It can be seen that PT BRI Tbk (Persero) Tbk has a higher value than the State Savings Bank Persero Tbk, meaning that PT BRI Tbk (Persero) Tbk is more maximal in using its assets to produce liquidity. In the Loan to Deposit Ratio ratio, the average value of PT BRI Tbk (Persero) Tbk and PT BTN Tbk (Persero) has exceeded the standard value determined at Bank Indonesia, which is between 85-110\%.

\section{CONCLUSION}

PT BRI Tbk (Persero) Tbk in general, in terms of the Profitability and liquidity of the financial performance of PT BRI Tbk (Persero) Tbk, better than the PT BTN Tbk (Persero). Tbk, then for PT BRI Tbk (Persero) Tbk in order to further improve its management ratio. In general, PT BTN Tbk (Persero)., In terms of management of Bank Negara Indonesia, is far better than PT BRI Tbk (Persero) Tbk. Profitability and liquidity.

Future research is expected not only to use five ratios in measuring the financial performance of PT BRI Tbk (Persero) Tbk with the PT BTN Tbk (Persero), it is better that future research uses more ratios to measure its performance. In addition, future research should also increase the sample so that the results are more generalized.

\section{REFERENCE}

Aabdel-Salam, Z., \& El-Sayed, A. (2014). Qualitative elemental analysis of farm animals' milk adopting laser spectroscopic technique. Indian Journal of Animal Sciences, 84(10), 1117-1120. https://www.scopus.com/inward/record.uri?eid=2-s2.0-

84908387049\&partnerID=40\&md5=b2a2bbf5cf602c779cac311c1ff05279

Ababneh, M. I. (2013). Obstetrics in a camel in an old North Arabian rock carving . Zeitschrift Der Deutschen Morgenlandischen Gesellschaft, 203-206. https://www.scopus.com/inward/record.uri?eid=2-s2.0-

84878713068\&partnerID=40\&md5=dcd07852d97c4d4fb9af345ef4c3fd27

Abad-González, J., \& Gutiérrez-López, C. (2016). Modeling banking solvency under adverse scenarios: Evidence from the "PIIGS" countries . Revista de Contabilidad-Spanish Accounting Review, 19(2), 227-238. https://doi.org/10.1016/j.rcsar.2015.11.002

Abad-Vivero, E. N., Thrasher, J. F., Arillo-Santillán, E., Pérez-Hernández, R., Barrientos-Gutíerrez, I., Kollath-Cattano, C., Mejía, R., \& Sargent, J. D. (2016). Recall, appeal and willingness to try cigarettes with flavour capsules: Assessing the impact of a tobacco product innovation among early adolescents. Tobacco Control, 25(e2), e113-e119. https://doi.org/10.1136/tobaccocontrol-2015- 
052805

Abarghani, A., Chaji, M., Mansori, H., Mamoei, M., Mirzadeh, K., \& Roshanfekr, H. A. (2019). Determination of some minerals concentration in the blood of dromedary camels of different sexes and physiological status. Journal of Veterinary Research, 74(3), 428-436. https://doi.org/10.22059/jvr.2018.247833.2742

Abbas, S. Z. M., Mahmud, R., \& Manan, N. S. A. (2017). Foreign ownership and performance of Islamic banks. Advanced Science Letters, 23(8), 7594-7596. https://doi.org/10.1166/asl.2017.9530

Abbas, Z., \& Faisal Rizwan, M. (2007). Abnormal accruals and firm value, panel data analysis of banking industry of Pakistan. European Journal of Scientific Research, 17(4), 445-454.

Abdul Hadi, A. R., Hussain, H. I., Suryanto, T., \& Eddy Yap, T. H. (2018). Bank's performance and its determinants - Evidence from middle east, Indian sub-continent and African banks | Wydajność banku i jej determinanty - Przykład bliskiego wschodu, indyjskich podwykonawczych oraz Afrykańskich banków. Polish Journal of Management Studies, 17(1), 17-26. https://doi.org/10.17512/pjms.2018.17.1.02

Abdul Hadi, A. R., Hussain, H. I., Suryanto, T., \& Yap, T. H. (2018). Bank's Performance and Its Determinants-Evidence from Middle East, Indian Sub-Continent and African Banks. Polish Journal of Management Studies, 17(1), 17-26. https://doi.org/10.17512/pjms.2018.17.1.02

Abdul Karim, M., Hassan, M. K., Hassan, T., \& Mohamad, S. (2014). Capital adequacy and lending and deposit behaviors of conventional and Islamic banks. Pacific Basin Finance Journal, 28, 58-75. https://doi.org/10.1016/j.pacfin.2013.11.002

Abdul Rahman, R., \& Masngut, M. Y. (2014). The use of “CAMELS" in detecting financial distress of Islamic banks in Malaysia. Journal of Applied Business Research, 30(2), 445-452. https://www.scopus.com/inward/record.uri?eid=2-s2.084894821893\&partnerID=40\&md5=bd4200c79896ce637890ce3f9f326979

Abdullah, H., Bujang, I., \& Sahudin, Z. (2017). Empirical investigation on loan loss provisions: Evidence from Hong Kong and Japan. Advanced Science Letters, 23(9), 8766-8770. https://doi.org/10.1166/asl.2017.9967

Aboagye, A. Q. Q., \& Ahenkora, E. (2018). Stress Testing Exposure of Banks to Sectors of the Ghanaian Economy. Journal of African Business, https://doi.org/10.1080/15228916.2017.1342180

Adeabah, D., Gyeke-Dako, A., \& Andoh, C. (2019). Board gender diversity, corporate governance and bank efficiency in Ghana: a two stage data envelope analysis (DEA) approach. Corporate Governance (Bingley), 19(2), 299-320. https://doi.org/10.1108/CG-08-2017-0171

Ahmad, N., Naveed, A., Ahmad, S., \& Butt, I. (2020). BANKING SECTOR PERFORMANCE, PROFITABILITY, AND EFFICIENCY: A CITATION-BASED SYSTEMATIC LITERATURE REVIEW. Journal of Economic Surveys, 34(1), 185-218. https://doi.org/10.1111/joes.12346

Akter, R., Ahmad, S., \& Islam, M. S. (2018). Camels model application of Non-Bank Financial Institution: Bangladesh perspective. Academy of Accounting and Financial Studies Journal, 22(1). https://www.scopus.com/inward/record.uri?eid=2-s2.085042652666\&partnerID=40\&md5=abdab25105f9ade991f2dee19c5a93c5

Ali, A. M. (2020). The impact of economic blockade on the performance of Qatari Islamic and conventional banks: a period-and-group-wise comparison. ISRA International Journal of Islamic Finance, 12(3), 419-441. https://doi.org/10.1108/IJIF-04-2020-0083

Ali, M., Riantani, S., \& Komariah, S. (2019). Analysis of factors affecting bank profitability (Study at PT Bank Rakyat Indonesia (PERSERO) TBK for the period 2004-2018). International Journal of Innovation, Creativity Change, 6(7), 95-106. https://www.scopus.com/inward/record.uri?eid=2-s2.085073166701\&partnerID=40\&md5=b051fee9ad745218dbb08584c9087ec3

An, P., \& Yu, M. (2018). Neglected part of shadow banking in China. International Review of Economics and Finance, 57, 211-236. https://doi.org/10.1016/j.iref.2018.01.005

Anggono, H. (2017). The determinant factors of asset and liability management and the bank performance: empirical study on foreign exchange commercial banks in Indonesia from 2008 to 2013. International Journal of Business and Globalisation, 19(4), 512-527. https://doi.org/10.1504/IJBG.2017.087298

Ariefianto, M. D., Widuri, R., Abdurachman, E., \& Trinugroho, I. (2020). The effect of competition and capacity on intermediation cost: A country level study. International Journal of Economics and Management, 14(1), 13-26. https://www.scopus.com/inward/record.uri?eid=2-s2.085084745958\&partnerID=40\&md5=da6a0a484d993abe705e6f7760a94f07

Dang, H. T. (2020). Determinants of Liquidity of Listed Enterprises: Evidence from Vietnam. Journal of 
Asian Finance, Economics and $\quad$ Business, 7(11),

https://doi.org/10.13106/jafeb.2020.vol7.no11.067

Dudchenko, V., Goncharenko, T., Didenko, O., \& Olejarz, T. (2020). Banking regulation in ensuring bank's efficiency: Looking through different forms of ownership. Journal of International Studies, 13(1), 342-358. https://doi.org/10.14254/2071-8330.2020/13-1/22

Erdawati, L., \& Bachtiar, M. (2018). Analisis Pertumbuhan Laba menggunakan pendekatan Camel Pada Bank Perkreditan Rakyat Di Tangerang Periode 2014-2016. Journal Accounting, 35-50.

Gazali, Kusuma, A., Aina, M., Bustaram, I., Amar, S. S., Rusdiyanto, Tjaraka, H., \& Panjilaksana, S. D. D. (2020). The Effect of Financial Performance on Stock Prices: a Case Study of Indonesian. Talent Development and Excellence, 12(1), 40074016. http://iratde.com/index.php/jtde/article/view/1351

Gazali, Kusuma, A., Aina, M., Bustaram, I., Risal, Z., Purwanto, Rusdiyanto, \& Tjaraka, H. (2020). Work Ethics of Madura Communities in Salt Business : A Case Study Indonesian. Talent Development and Excellence, 12(1), 3537-3549. http://iratde.com/index.php/jtde/article/view/1312

Hartono, \& Diansyah. (2018). Pengaruh Kinerja Keuangan Terhadap Harga Saham Bank Umum Swasta Nasional Yang Terdaftar Di Bursa Efek Indonesia. Journal of Business Studies, 3(1), 45-57.

Hermanto, B., Rahayu, S., \& Yudi. (2018). Pengaruh Rasio Keua ngan Terhadap Perubahan Laba (Studi Empiris Pada Bank Pembangunan Daerah Se-Sumatera) Tahun 2011-2017. Journal Accounting, 4052.

Hristov, J., Clough, Y., Sahlin, U., Smith, H. G., Stjernman, M., Olsson, O., Sahrbacher, A., \& Brady, M. V. (2020). Impacts of the EU's Common Agricultural Policy "Greening" Reform on Agricultural Development, Biodiversity, and Ecosystem Services. Applied Economic Perspectives and Policy, 42(4), 716-738. https://doi.org/10.1002/aepp.13037

Ibrahim, M. H., \& Law, S. H. (2020). Financial intermediation costs in a dual banking system: The role of islamic banking. Buletin Ekonomi Moneter Dan Perbankan, 22(4), 529-550. https://doi.org/10.21098/bemp.v22i4.1236

Indonesia, M. N. S. N. R. (1998). UNDANG-UNDANG REPUBLIK INDONESIA NOMOR 10 TAHUN 1998. Undang Undang RI No 10 Tahun 1998, 1-20.

Juanamasta, I. Gede, Wati, N. M. N., Hendrawati, E., Wahyuni, W., Pramudianti, M., Wisnujati, N. S., Setiawati, A. P., Susetyorini, S., Elan, U., Rusdiyanto, R., Astanto, D., Ulum, B., Khadijah, S. N., Trimarjono, A., Syafii, M., Mubarroq, A., Kristiningsih, K., Pratiwi, R. D., Veri, V., ... Umanailo, M. C. B. (2019). The role of customer service through customer relationship management (Crm) to increase customer loyalty and good image. International Journal of Scientific and Technology Research, 8(10), 2004-2007.

Juanamasta, I.G., Wati, N. M. N., Hendrawati, E., Wahyuni, W., Pramudianti, M., Wisnujati, N. S., Setiawati, A. P., Susetyorini, S., Elan, U., Rusdiyanto, R., Astanto, D., Ulum, B., Khadijah, S. N., Trimarjono, A., Syafii, M., Mubarroq, A., Kristiningsih, K., Pratiwi, R. D., Veri, V., ... Umanailo, M. C. B. (2019). The role of customer service through customer relationship management $(\mathrm{Crm})$ to increase customer loyalty and good image. International Journal of Scientific and Technology Research, 8(10).

Juanamasta, I.G., Wati, N. M. N., Hendrawati, E., Wahyuni, W., Pramudianti, M., Wisnujati, N. S., Setiawati, A. P., Susetyorini, S., Elan, U., Rusdiyanto, R., Muharlisiani, L. T., \& Umanailo, M. C. B. (2019). The role of customer service through customer relationship management (Crm) to increase customer loyalty and good image. International Journal of Scientific and Technology Research, 8(10), 2004-2007.

Julsrud, T. E., \& Denstadli, J. M. (2020). Moving small crafts and services enterprises towards green mobility practices: The role of change agents. Environmental Innovation and Societal Transitions, 37, 254-266. https://doi.org/10.1016/j.eist.2020.09.003

Kerléo, J.-F. (2020). Project administration: Sustaining provisional and agility in the public sector [L'administration de projet: Pérenniser le provisoire et l'agilité dans les structures publiques]. Revue Francaise d'Administration Publique, 175(3), 721-734. https://doi.org/10.3917/rfap.175.0721

Killins, R. N., \& Mollick, A. V. (2020). Performance of Canadian banks and oil price movements. Research in International Business and Finance, 54. https://doi.org/10.1016/j.ribaf.2020.101258

Kim, K. H., Nam, M. S., Hwang, H. H., \& Ann, K. Y. (2020). Prediction of remaining life for bridge decks considering deterioration factors and propose of prioritization process for bridge deck maintenance. Sustainability (Switzerland), 12(24), 1-25. https://doi.org/10.3390/su122410625

Masood, O., Ghauri, S. M. K., \& Aktan, B. (2016). Predicting Islamic banks performance through CAMELS rating model. Banks and Bank Systems, 11(3), 37-43. https://doi.org/10.21511/bbs.11(3).2016.04

McCue, M. J., \& Stack, R. T. (2015). Assessing the financial performance of health insurers paying a rebate under ACA. Journal of Health Care Finance, 42(1). https://www.scopus.com/inward/record.uri?eid=2-s2.085019427450\&partnerID $=40 \&$ md5 $=4454$ bec $2534 \mathrm{~d} 5$ e33bbe $6 \mathrm{~b} 365$ febbdbf3 
Merikas, A., Merika, A., Penikas, H. I., \& Surkov, M. A. (2020). The Basel II internal ratings based (IRB) model and the transition impact on the listed Greek banks. Journal of Economic Asymmetries, 22. https://doi.org/10.1016/j.jeca.2020.e00183

Meslier, C., Risfandy, T., \& Tarazi, A. (2020). Islamic banks' equity financing, Shariah supervisory board, and banking environments. Pacific Basin Finance Journal, 62. https://doi.org/10.1016/j.pacfin.2020.101354

Murphy, E. V. (2014). Financial stability oversight council: A framework to mitigate systemic risk. In Asset Management Firms, Financial Stability and the FSOC: Elements and Considerations. https://www.scopus.com/inward/record.uri?eid=2-s2.084948779555\&partnerID=40\&md5=8b5f77833145d43414f356c50381ab9e

Naseri, M., Bacha, O. I., \& Masih, M. (2020). Too Small to Succeed versus Too Big to Fail: How Much Does Size Matter in Banking? Emerging Markets Finance and Trade, 56(1), 164-187. https://doi.org/10.1080/1540496X.2019.1612359

Navas, J., Dhanavanthan, P., \& Lazar, D. (2020). How Have Indian Banks Adjusted Their Capital Ratios to Meet the Regulatory Requirements? An Empirical Analysis. Journal of Asian Finance, Economics and Business, 7(11), 1113-1122. https://doi.org/10.13106/jafeb.2020.vol7.no11.1113

Pekkaya, M., \& Demir, F. E. (2018). Determining the priorities of CAMELS dimensions based on bank performance. Contributions to Economics, 445-463. https://doi.org/10.1007/978-3-319-784946_21

Peled, Y., Zemah Shamir, S., Israel, A., Shechter, M., Ofir, E., \& Gal, G. (2020). Incorporating insurance value into ecosystem services assessments: Mitigation of ecosystem users' welfare uncertainty through biological control. Ecosystem Services, 46. https://doi.org/10.1016/j.ecoser.2020.101192

Piu, R., Murni, S., \& Untu, V. (2018). Analisis Banking Comparison Healt By Using The Method RGEC The Bank Book Four Conventional Public. Jurnal EMBA, 6(2), 738-747.

Prabowo, B., Rochmatulaili, E., Rusdiyanto, \& Sulistyowati, E. (2020). Corporate governance and its impact in company's stock price: case study [Gobernabilidad corporativa y su impacto en el precio de las acciones de las empresas: Estudio de caso]. Utopia y Praxis Latinoamericana, 25(Extra10), 187-196. https://doi.org/10.5281/zenodo.4155459

Rashid, A., \& Jabeen, S. (2016). Analyzing performance determinants: Conventional versus Islamic Banks in Pakistan. Borsa Istanbul Review, 16(2), 92-107. https://doi.org/10.1016/j.bir.2016.03.002

Rout, C. K., Swain, P. K., \& Dash, M. (2019). Predictive analytics in harnessing financial efficacy of banks using camel model. International Journal of Management, 10(6), 177-190. https://doi.org/10.34218/IJM.10.6.2019.018

Rusdiyanto, Agustia, D., Soetedjo, S., \& Septiarini, D. F. (2020). The effect of cash turnover and receivable turnover on profitability. Opcion, 36(26), 1417-1432. https://doi.org/10.1017/CB09781107415324.004

Rusdiyanto, Agustia, D., Soetedjo, S., \& Septiarini, D. F. (2020). The effect of cash turnover and receivable turnover on profitability | El efecto de la rotación de efectivo y la rotación de cuentas por cobrar en la rentabilidad. Opcion, 36(Special Ed), 1417-1432.

Rusdiyanto, Hidayat, W., Soetedjo, S., Tjaraka, H., Septiarini, D. F., Gazali, Herli, M., Ulum, B., Syafii, M., Irawan, H., \& Rahayu, D. I. (2020). The Effect of Macroeconomics on Stock Prices: Case Study Indonesian. Espacios, 14(17), 26. https://www.revistaespacios.com/a20v41n17/20411726.html

Rusdiyanto, Hidayat, W., Tjaraka, H., Septiarini, D. F., Fayanni, Y., Utari, W., Waras, Indrawati, M., Susanto, H., Tjahjo, J. D. W., Mufarokhah, N., Susetyorini, Elan, U., Samsi, N., Choiri, Hudha, M. S., Muji Widodo, Suryanto, H., Abidin, M. Z., \& Imanawati, Z. (2020a). The Effect of Earnig Per Share, Debt to Equity Ratio and Return on Assets on Stock Prices: Case Study Indonesia. Academy of Entrepreneurship Journal, 26(2), 1-10. https://www.abacademies.org/articles/The-effect-of-earning-per-share-debtto-equity-ratio-and-return-on-assets-on-stock-prices- 1528-2686-26-2-338.pdf

Rusdiyanto, Hidayat, W., Tjaraka, H., Septiarini, D. F., Fayanni, Y., Utari, W., Waras, Indrawati, M., Susanto, H., Tjahjo, J. D. W., Mufarokhah, N., Susetyorini, Elan, U., Samsi, N., Choiri, Syamsul, M., Widodo, M., Suyanto, H., Zainal, M., \& Imanawati, Z. (2020b). The effect of earning per share, debt to equity ratio and return on assets on stock prices: Case study Indonesian. Academy of Entrepreneurship Journal, 26(2).

Rusdiyanto, Hidayat, W., Tjaraka, H., Septiarini, D. F., Fayanni, Y., Utari, W., Waras, Indrawati, M., Susanto, H., Tjahjo, J. D. W., Zainal, M., \& Imanawati, Z. (2020). The effect of earning per share, debt to equity ratio and return on assets on stock prices: Case study Indonesian. Academy of Entrepreneurship Journal, 26(2), 1-10.

Rusdiyanto, \& Narsa, I. M. (2019). The Effects of Earnings Volatility, Net Income and Comprehensive Income on Stock Prices on Banking Companies on the Indonesia Stock Exchange. Internasiotional 
Review of Manahement and Marketning, 9(6), 18-24. https://doi.org/https://doi.org/10.32479/irmm.8640

Rusdiyanto, \& Narsa, I. M. (2020). The Effect of Company Size , Leverage and Return on Asset on Earnings Management : Case Study Indonesian. Espacios, 41(17), 25.

Rusdiyanto, Sawarjuwono, T., \& Tjaraka, H. (2020). Interpret The Shari ' ah Accounting Practice In Indonesian. Talent Development and Excellence, 12(3), 2420-2433. http://iratde.com/index.php/jtde/article/view/1102

Rusdiyanto, Tjaraka, H., Mufarokhah, N., Al'Aslaini, M. Z., Musthofa, A. J., Aji, S., Zainab, \& Rohmah, A. (2019). Corporate Social Responsibility Practices in Islamic Studies in Indonesian. Talent Development and Excellence, 12(1), 121-139. https://doi.org/10.4324/9780429057182-8

Sani, H. S., Amboningttyas, D., \& Yulianeu. (2018). Comparative Analysis of the Financial Performance of Banks BCA And Banks Mega. Jurnal Accounting, 1-10.

SASIDHARAN, S., RANJITH, V. K., \& PRABHURAM, S. (2020). Micro- and Macro-Level Factors Determining Financial Performance of UAE Insurance Companies. Journal of Asian Finance, Economics and Business, 7(12), 909-917. https://doi.org/10.13106/JAFEB.2020.VOL7.N012.909

Suryansyah, A. H., \& Rusdiyanto. (2016). Studi Rasio Keuangan Terhadap Kinerja. Jurnal Penelitian Ekonomi Dan Akuntansi, 1(2), 147-158.

Syafii, M., Ulum, B., Rusdiyanto, Suparman, P., Rahayu, D. I., \& Syasindy, N. B. (2020). The effect of financial performance on the company's share price: A case study Indonesian. European Journal of Molecular and Clinical Medicine, 7(8), 1055-1071. https://www.scopus.com/inward/record.uri?eid=2-s2.085098454552\&partnerID=40\&md5=10d4ddcf32dd4bf918ba3622c11e86dd

Syahputra, R., \& Ahsanul Fuad Saragih. (2018). Analisis Tingkat Kesehatan Bank dengan Metode Camel Pada PT Bank Artos Indonesia Tbk Periode 2014-2017. Jurnal Administrasi Bisnis, 4(1), 37-45.

Wijaya, C., Lucianna, Y., \& Indriati, F. (2020). Determinants of interest rate spreads of conventional banks listed on the Indonesia Stock Exchange. Banks and Bank Systems, 15(4), 69-79. https://doi.org/10.21511/bbs.15(4).2020.06 